\title{
Teaching in linguistically and culturally diverse secondary schools
}

\section{How far have we come?}

\author{
Margaret Gleeson and Chris Davison \\ Victoria University of Wellington University of New South Wales
}

\begin{abstract}
Thirty years ago Australian researchers led the development of language and content integration in schools, advocating systematic teaching of language across the curriculum to meet the needs of English as an additional language (EAL) students. However, despite significant improvements in initial teacher education, targeted professional development and language-specific curriculum and assessment, this paper suggests that secondary teachers have gained only a superficial understanding of the language knowledge necessary to teach EAL students. Drawing on questionnaires, interviews, and observations, this case study of two secondary schools in Sydney reveals the majority of teachers report their perspectives and experiences of good teaching have equipped them with a repertoire of sufficient strategies to meet EAL needs, and they see little difference between teaching EAL and learners with low levels of literacy. This paper concludes a renewed focus on integrating language and content teaching and partnership models of professional learning and evaluation are needed.
\end{abstract}

Keywords: English language learners, content and language integrated curricula, subject teachers, content teachers, teacher professional development

\section{Introduction}

Australia is a linguistically and culturally diverse nation with over a quarter of its population born overseas and $21 \%$ of Australians speaking one or more of 300 languages other than English at home, with the most populous state, New South Wales, containing the most people born overseas, and $25.2 \%$ of the population of its capital city, Sydney, speaking a language other than English at home in 2016 
(ABS, 2018). In NSW schools, there was a $62 \%$ increase in EAL learners between 2012-2014, with no extra EAL teacher support; in 2014 alone, 138,487 students were identified as needing EAL support, but only 91,401 received it. ${ }^{1}$

Given the very high numbers of students for whom English is a second or additional language (ESL/EAL) attending Australian schools, all initial teacher education programs in Australia are now required to address the needs of students learning in and through English as an additional language (EAL) as a national priority area, including "effective teaching and learning strategies for teaching second language learners in the context of the mainstream classroom and the range of key learning areas" and "knowledge of the cultural and language demands and biases of classroom resources" (New South Wales [NSW] Education Standards Authority [NESA], 2017, p. 13). Love (2010) describes how teaching language/literacy pedagogical content knowledge can be included in core programs, and gives the example of how this works in a Master of Teaching (secondary) programme, and many examples of good practice in initial teacher education are being promulgated in the literature (for example, Ollerhead, 2017; Premier \& Miller, 2010).

Many secondary schools have also completed professional learning in this area, either the ESL in the Mainstream course, developed in the 1980s, or in NSW more commonly the Teaching English Language Learners (TELL) In-service Course (Department of Education NSW, undated), which consists of 6 modules, with each being of 2 hours duration. In addition, there are between-session readings and tasks that along with the modules make up "a comprehensive program of professional learning to support teachers of EALD learners across the range of school subject areas" (p. 1), underpinned by a systemic functional linguistic view of language as a resource for meaning-making.

A wealth of curriculum and assessment resources has also been published to support teachers of EAL students in the content areas (for example, see the English as an Additional Language or Dialect Teacher Resource, to support teachers in the Australian Curriculum: Foundation to Year 10 with students for whom English is an additional language or dialect (EAL/D), https://acara.edu.au/curriculum /student-diversity/english-as-an-additional-Language-or-dialect). In addition, in a ground-breaking step in mainstream curriculum development, the curriculum

1. English as an Additional Language/Dialect (EALD) education in NSW is provided in primary and secondary schools and in intensive English language centres to support the English language development of students whose first language is not English. In these schools, EALD programs are delivered in a variety of ways to meet the different needs of EALD students at different stages of learning English, focusing on students learning English in the context of the curriculum they are studying so that they acquire the English language skills relevant to the subject area. Students may receive support from a specialist EALD teacher working with a class teacher or they may be in a separate parallel group for some classes. 
systematically links the content of key learning areas to the functions and features of the language needed to be successful in the area (for example, see http://docs .acara.edu.au/resources/EALD_Learning_Area_Annotations_Science_Revised _February_2014.pdf for the ways in which the Science curriculum makes explicit the subject-specific nature of its language and literacy requirements). All learning areas in the curriculum specify the text types and language forms required to speak, read and write within the specific content area.

Given these important developments, including the focus on explicit teaching about the nature and purpose of language in the content areas, it is timely to examine how far we have come in meeting the needs of EAL students in secondary schools.

\section{Literature review}

It has been more than 30 years since Australian researchers and policy makers first began advocating for the integration of language and content instruction across the curriculum to better meet the needs of the rising proportion of culturally and linguistically diverse students in secondary schools (Davison, 1988; Davison \& Williams, 2001), that is, systematic planned language development, not just the inclusion of EAL students in the ongoing activities of the mainstream classroom. Internationally, it is now widely recognized that immersing English language learners in content-area classrooms by itself is not an adequate solution to language and cognitive/academic development (Hurst \& Davison, 2005; Gibbons, 2009, 2014; Hammond, 2014). Learning to use English for academic purposes requires considerably more time than is the case for conversational or social English (Cummins \& Early, 2011); simply placing students in English-medium mainstream classes cannot be assumed to provide optimal language learning opportunities.

In the 1980s, Australia was one of the first countries in which significant critiques of the notion of language as communicative competence and the subsequent separation of language and content gained widespread acceptance, leading to significant changes to curricula (Davison, 1993; Davison \& Williams, 2001; Lo Bianco, 1990). Halliday's (1978) view that the uses of language are inseparable from its social functions, with language defined in terms of its meaning potential, as a set of linguistic choices to be made, explicitly challenged the separation of language and content. Educational linguists working within a Hallidayan linguistic perspective (Halliday, 1993; Martin \& Rose, 2008) identified the critical role of language in the knowledge building of school disciplinary content (Christie \& Derewianka, 2010; Martin, 2013; Unsworth, 1999). This internationally recog- 
nized body of research has informed a number of studies (Love \& Humphrey, 2012; Morgan, Craig, Schuette, \& Wagner, 2014; Schleppegrell, 2013; Veel, 1997, 2006) which have found that teachers' enhanced knowledge of key meaningmaking systems result in enhanced student understandings of academic concepts.

Researchers now advocate for the inclusion of "Knowledge About Language" (KAL) in teacher education (Bunch, 2013; Hammond \& Jones, 2012; Love, 2010; Ollerhead, 2017). Content teachers and their professional developers are urged to see relevance of KAL for each particular subject and understand language as a meaning making tool. A basic knowledge of the genres and their key linguistic features is needed to build teachers' capacity to: identify and explain the increasingly technical and abstract discourse across the years of schooling, make discipline knowledge visible and accessible to their students, describe the cumulative building of knowledge across the school years in ways that contribute to effective pedagogy, and build understandings of the interaction of language and other meaningmaking systems in the representation of knowledge (Christie \& Derewianka, 2010; Gibbons, 2008; Halliday, 1993; Rose \& Martin, 2012; Seah, Clarke, \& Hart, 2011). However, in practice, the literature suggests the language focus in content areas is still limited to subject vocabulary (Gleeson, 2015; Phillips \& Norris, 2009), as that is the most transparent aspect of the English language system for contentarea teachers.

Further support is necessary in preparing teachers to teach students how language is used in specific subject areas (Lee \& Buxton, 2013). For instance, articulating scientific knowledge is a critical task. To illustrate, where EAL students are expected to provide evidence-based explanations of scientific processes, they may need explicit modelling and teaching of conditional tenses, for example, if $x$ then $y$; if $x$ occurred then $y$ would occur; if $x$ had occurred then $y$ would have occurred (ACARA, 2012). However, research suggests that learning about the language of science continues to be a major challenge for students and their teachers (De Oliveira \& Lan, 2014; Fang, 2005; Wellington \& Osborne, 2001). Even teachers with an understanding of models of language rarely demonstrate metalinguistic awareness - an ability "to extract themselves from the normal use of language and focus their attention on the functions and forms of the language" (Masny, 1997, p. 106). Concerns have also been raised that pre-service and in-service education for teachers continues to foreground subject content and little attention is paid to language (Gleeson \& Davison, 2016; Polat \& Mahalingappa, 2013). When practising teachers receive professional development, it is more often geared to new standards or curricula than to language issues, hence many mainstream secondary school teachers feel inadequately prepared to meet EAL needs (Reeves, 2006). 
There is little evidence of secondary schools systematically integrating language instruction with content knowledge (Echevarria, Vogt, \& Short, 2008; Turkan, De Oliveira, Lee, \& Phelps, 2014), despite the fact that researchers have long advocated for the integration of content-based EAL teaching and EALconscious content teaching into the secondary school (Davison \& Williams, 2001; Echevarria, Frey, \& Fisher, 2015). Two pervasive beliefs about EAL learning and teaching have been identified as entrenched barriers to the implementation of such approaches in secondary schools: firstly, the belief that EAL teaching is a set of strategies rather than curricular content (Hurst \& Davison, 2005; Davison, 2006), and secondly, the assumption that there is no difference between teaching language and teaching literacy. Literacy is too often seen as a substitute for "English", for "language" and for "oracy" in a way which is often perceived to undermine and distort the learning and teaching task (Davison, 1993). Hence, this paper investigates the beliefs and practices of teachers in two secondary schools to ascertain the extent to which they integrate language and content instruction into the content areas.

\section{Method}

This study was conducted with secondary subject teachers in two large urban schools in Sydney, NSW. The two schools were purposively selected for their large LOTE student population, their engagement with EAL students, and their proximity to an Intensive English Centre (IEC). Eleven teachers volunteered from subject areas including history, ICT, geography, mathematics, science, visual arts, English, learning support and ESL, see Table 1.

The teachers of EAL and learning support commonly team-taught in additional subject areas such as science, mathematics geography and music, or integrated studies. One participant was the head of the IEC with responsibility for preparing new arrivals for entry to secondary school. The teachers had teaching experience that varied from less than two years' to more than 20 years' experience. Some had middle or senior management positions and two held responsibility for the placement and progress of EALs in their large urban secondary schools. They chose to participate in the study after senior managers at their schools shared details about the research objectives.

The participants completed a short questionnaire that prompted them to think about language teaching and learning in their disciplines. The questionnaire items were used as prompts for individual semi-structured interviews that took place at the school. Interview data were transcribed and analysed thematically. 
Table 1. Participants

\begin{tabular}{|c|c|c|c|c|c|}
\hline Pseudonym & Gender & $\begin{array}{c}\text { Years of } \\
\text { teaching } \\
\text { experience }\end{array}$ & $\begin{array}{l}\text { Teaching } \\
\text { area }\end{array}$ & $\begin{array}{l}\text { TESOL } \\
\text { qualifications }\end{array}$ & PD \\
\hline Simon & Male & 7 & $\begin{array}{l}\text { Head of } \\
\text { Learning } \\
\text { Support/ } \\
\text { English }\end{array}$ & $\begin{array}{l}\text { Dip Ed (ESL } \\
\text { major) }\end{array}$ & - \\
\hline Rosa & Female & 2 & $\begin{array}{l}\text { Learning } \\
\text { Support }\end{array}$ & - & Grammar and teaching \\
\hline Marie & Female & 1st year & Science & - & \\
\hline Marlene & Female & 25 & $\begin{array}{l}\text { Head of } \\
\text { Learning } \\
\text { Support/ } \\
\text { English }\end{array}$ & - & $\begin{array}{l}\text { Teaching English Language } \\
\text { Learners (TELL), ESL } \\
\text { conferences }\end{array}$ \\
\hline Nell & Female & 10 & $\begin{array}{l}\text { Learning } \\
\text { Support/ } \\
\text { English }\end{array}$ & - & ESL in the mainstream \\
\hline Shona & Female & 21 & Visual art & - & - \\
\hline Rick & Male & 19 & $\begin{array}{l}\text { History, } \\
\text { Society, and } \\
\text { Culture }\end{array}$ & Dip TESOL & \\
\hline Beth & Female & 20 & $\begin{array}{l}\text { Intensive } \\
\text { English } \\
\text { Centre }\end{array}$ & Dip Ed (ESL) & "Ongoing and continuous" \\
\hline Neil & Male & 35 & $\begin{array}{l}\text { Indonesian, } \\
\text { ESL }\end{array}$ & $\begin{array}{l}\text { Dip Ed } \\
(\mathrm{TEFL})\end{array}$ & \\
\hline Karl & Male & 22 & Maths & - & In-service PD \\
\hline Salma & Female & 20 & $\begin{array}{l}\text { Focus on } \\
\text { Reading }\end{array}$ & $\mathrm{n} / \mathrm{a}$ & $\mathrm{n} / \mathrm{a}$ \\
\hline
\end{tabular}

This paper reports the views of these teachers about teaching EALs and English language in their content areas.

\section{Findings}

Systematic and iterative analysis of the data revealed that the teachers' reported beliefs about teaching EALs could be captured by two overarching themes: Language teaching is included in good teaching and Language teaching is included in literacy teaching. Their views about language and language learning fell into one or both of these categories, elaborated below. 


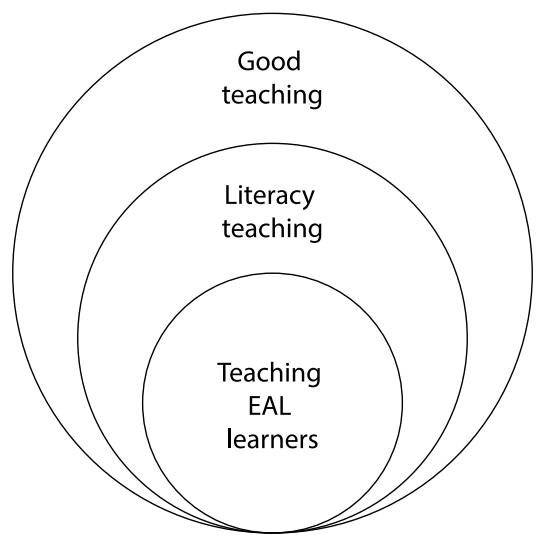

Figure 1. Teachers' conceptions of knowledge for teaching language

\subsection{Theme 1: Language teaching is included in good teaching}

The participants reported using a number of teaching practices that were consistent with research about accelerating the learning of EALs, and good teaching in general, but seemed to believe that there was no specialist knowledge required to be effective teachers of EALs. For instance, all of the participants were conscious of the importance of connecting with students' interests and prior learning. Nell constructed social studies lessons around episodes of Bear Grylls; Rick drew on his students' cultural knowledge and religious convictions in his history classes and Karl captured his students' interest in mathematics by focusing lessons on money and cars. Shona felt that sharing learning objectives and setting success criteria empowered students to play an active role in their learning (though she felt that language learning objectives would be a step too far). This learning process was dependent on providing timely feedback:

Explicit feedback is critical to the students to improve them, their results, and improving their writing. ... a huge part of ESL students' progression in the English language with writing and with reading, but for writing it's feedback....we get English students to work over the answer, to look at the standard, look at the rubric, interpret and assess themselves ... And it all demands good feedback for the students.

(Salma, Head Teacher Learning Support)

According to several participants, learning for EAL students, as for every student, should begin with rich tasks that allow for concepts to be represented in different ways using different media: "We'll cover the content, then we'll watch a video that relates to that, then we'll discuss it" (Marie, Science). ICT was considered to be highly motivating and for this reason believed to be effective in promoting language learning. Interactive whiteboards and engaging software packages 
(Edmodo, Testmaster, Prezzie) were tools recommended by Shona (Visual Arts). Experiential learning and learning that included visual aids were also favourite techniques for teaching EALs:

I think providing lots of visuals is important... I think lots of language development [strategies] like barrier games and stuff.

(Nell, Special Needs)

There was consensus that modelling would benefit EAL students and the teachers went about this in different ways. A popular approach was deconstructing past examination papers to familiarise students with the expectations for HSC.

I write a model. But they should see a lot of models because there's such a reliance on past papers here, so even if we give them past papers, they're always with solutions as well. So they have models there to look at too for those kinds of questions.

(Karl, Mathematics)

One subject teacher who had EAL qualifications was very specific about modelling subject specific writing:

If you want them to do an essay, you've got to show them how an essay works. You've got to put it up on the board, you know: This is what you need to include in introduction... you need this thesis statement that's got to explain all the different aspects of where the essay is going. And you've got to have a topic sentence in each of the paragraphs.

(Rick, History)

This approach was supported and clearly explained by a senior teacher at his school:

In history there is the discussion text type... expositions are huge in respect of what students do in an examination or in an assessment. What we do to scaffold them is we absolutely explicitly show the students what the text type looks like and provide them with examples of what this text type looks like. We provide them a range of examples as well. What I also do is ... deconstruct, so once you've shown them what the whole text type looks like and we have looked at the structure, the form and features, of what constitutes this text type, what it's all about. We pull it apart and deconstruct it. On the opposite side of that we also construct one.

(Salma, Head Teacher Learning Support)

However, only these two teachers were able to articulate the role of genres and text purposes in developing academic language.

There was a strong sense that oral language was important for engaging EAL learners, especially for those from families who were illiterate in their L1, though they did not articulate why it supported language learning. One teacher described how she made a bridge between colloquial and written-like language: "I'll put it 
into a simple, sort of common term as I can. Then, in brackets next to the simple word, I'd put the more scientific term" (Marie, Science). Other teachers agreed that talk would lead to learning: “They've got to be able to talk because if they can't talk, they're not understanding it properly" (Rick, History).

The EAL teachers shared that structured interactive tasks such as jigsaw reading would enhance language learning, but shied away from group tasks because they could be difficult to manage with lively classes. Most subject teachers preferred talk to occur in whole class discussions, which suggests that their reason for discussion was managerial rather than to promote language learning. They explained that students were likely to go off-task in small group activities but they could monitor learning in whole class tasks.

The teachers had mixed opinions about students speaking in their L1. Some felt that it would inhibit learning the L2 (English), but many believed that the L1 enabled EAL students to engage in higher levels of thinking:

There's a limit [to the information] that I get across to them but they can talk about it and that way I can find out actually if they know the idea, understand the idea in their own language.

(Karl, Mathematics)

The rationale was that: "Your second language can never be better than your first and so I think they need to keep pushing on with their first language" (Neil, ESL). One senior teacher also felt that the $\mathrm{L}_{1}$ was a means to create positive links with the families:

It's very important to allow students in ESL to be able to use vocabulary concepts in their own language. And so a technique that I have used all the time is... I ask students to then spend a little bit [of time] at home on what that word translates to in their own language.

(Salma, Head Teacher Learning Support)

This theme illustrates that teachers favoured a number of approaches to teaching and learning and teaching strategies that have been found to promote language learning. However, it did not appear that these positive conceptions of EALs' learning were underpinned by a strong foundational knowledge about language, rather had been shaped by their professional experiences.

\subsection{Theme 2: Language teaching is included in literacy teaching}

All of the subject teachers in the study felt confident that they understood how to teach EALs because their schools had such a high proportion of EALs and they were used to teaching such learners. However, the participants' remarks suggested that they believed that EAL students were on a similar learning trajectory to students who struggled to acquire literacy in their dominant language (L1): 
I look at the ESL stuff, and I did that 11 week ESL in the Mainstream course,... and lots of them were just literacy strategies and I don't know if this sounds naive but they look a lot like what we use in English, you know: scaffolding and background knowledge.

(Nell, Special Needs)

They were a little wary of the metalanguage of ESL:

We learnt about, and we use relevant texts and stuff like that. I remember that from ESL but I don't know about all the first phase development ... And you know how ESL people use that talk.

(Nell, Special Needs)

This teacher struggled to distinguish between literacy and language learning:

ESL is more about communication and function in the society... literacy is more focussed within an environment like school where there's a lot of writing, there's a lot of reading and things like that.

(Rosa, Learning Support)

There seemed to be an assumption that teaching English as a second language (ESL) differed from academic literacy in that the purpose of EAL was to develop functional language: "It's all about transitioning them into the work place" (Marlene, Head of Teaching and Learning).

The teachers seemed familiar with literacy strategies designed for learners in low stream classes and tried to apply these across the curriculum:

The challenge to me are the other kids who can't write well. So we've looked at some literacy stuff for them... there's all sorts of plans but to take it down to the level to some of these kids, it's a lot of visuals.

(Nell, Special Needs)

Although the focus of the interviews was specifically on (second) language learning, another teacher summed up the faculty-wide confidence and sense of expertise for teaching EALs: "In visual arts we are literacy queens" (Shona, Visual Arts).

Several teachers felt that "teaching EALs was similar to teaching at primary school level". Another worried that her language teaching skills might be limited because she was "not primary trained". However, she worked to apply what she had learnt from colleagues through her school's partnership with a primary school:

I went across to a class in primary school and they used like lots of different strategies like predicting, you know, with text... and there is another strategy where you get them to draw what they think might be in the text ...we know the word metacognition and I always put it on a board!... I try not to talk too much... But to show them those strategies, and they benefit learners of all abilities.

(Nell, Special Needs) 
The literacy approaches promoted through partnerships with the local primary school were seen to promote language development, but some participants were unaware that literacy practices and assessments designed for children learning in their first language (L1) may not be appropriate for EAL learners in a cognitively demanding secondary context:

It's been so informative seeing what the primary school's doing, because we have a lot of students that fall into primary age reading groups. (Shona, Visual arts)

While the belief that learning an L1 and L2 was much the same was inferred by many of the participants, it was evident that at least one other participant appreciated the different cognitive and generic demands faced by secondary school EAL learners. One reflected on a grammar course she was taking:

[On this course] there's a bit more of a focus towards the primary school setting and things like recounts and retellings and stories and things about the kids' personal kind of lives. I mean that can be transferred into high school settings... But, to me high school is not just about that, you've got content to teach as well.

(Rosa, Learning Support)

Many of the teachers felt that the best way to promote an EAL student's literacy and thus language proficiency was to focus on decontextualized grammatical structures: "They actually need some time in a small group just to focus on like the mechanics of language" (Simon, Head of Teaching and Learning), and mastery of phonics:

Our teacher aides work basically through the multi-lit programme which focuses on things like sight word recognition and blending sounds at the decoding level.

(Simon, Head of Teaching and Learning)

Non-native-like pronunciation was believed to indicate limited proficiency in English:

Every time I am talking about a student who is shy or, or a student who may not be able to pronounce things, I'm always thinking of ESL learners.

(Shona, Visual Arts)

Similarly, incorrect spelling was taken as a strong indicator that an EAL student had limited comprehension:

We concentrate on the word level because based on the assessment tasks I've done, I find that they don't know how to spell properly which is why we focus on getting them to spell.

(Marie, Science) 
It was generally agreed that EAL students learn language best starting at the word level: "Their language levels are very very low, so it's simple plurals, it's simple past tenses, it's simple construction" (Rick, History). The word level included a focus on pre-teaching technical vocabulary:

Because the subject has a terminology that's specific to it, you've got to spend a little time on basically getting them familiar with that. It's vocab particularly: glossary of terms, meaning, and things like that because even though they may know the term in one subject, [it] might be different completely in meaning in history.

(Rick, History)

This also sometimes required the EAL teacher to unpack words at the prefix and root level:

I enjoy working in science classes because there's so much technical vocabulary, and being able to break those words down you know with [my] language background you can break down these words down into the smallest chunks and explain what little bits of the words mean.

(Neil, ESL)

Once students were proficient at the word level, it was considered to be time for them to begin to construct sentences: "Lots of the kids that I'm working with are at sentence level" (Nell, Special Needs). Only then were students expected to move to the paragraph level: "The school has a structure that we work with in terms of how we structure a paragraph" (Rosa, Learning Support).

The participants agreed that paragraph level was the most complex and extensive level of writing needed in their disciplines, and extra marks were awarded in examinations when students could demonstrate their command of an explanation. However, even though some teachers were very methodical in deconstructing and reconstructing paragraphs, paragraphs were rarely described or taught according to text type.

When EAL was differentiated from literacy, it was primarily defined by particular teaching strategies:

Traditional mainstream English teaching just didn't work with the boys that we were teaching. So I've come to rely more and more on the ESL methodologies. And I guess through my role as Head Teacher Teaching and Learning I've tried to get them used more consistently across the school in all KLAs.

(Simon, Head of Teaching and Learning)

You need to be able to have a look at a kid's writing and be able to identify [what isn't working] and give them the strategies.

(Rosa, Learning Support) 
Yet teaching students with English as an additional language was not generally perceived as a specialist field, even by teachers who had studied EAL as a teaching area. This was underlined by how the faculties in both schools were structured. Planning for teaching EAL learners was primarily the responsibility of the Faculty of Teaching and Learning in both schools, but in the teachers' minds, EAL was perceived as fitting within curriculum English and the assumption seemed to be that trained English teachers would have the necessary skills:

While I don't have ESL training, I had taught, obviously this is an ESL school, in every classroom anyway and I had taught the ESL at HSC course because at that time when I come here it was being taught by mainstream English teachers.

(Marlene, Head of Teaching and Learning)

EAL was also often equated to learning support, with one teacher noting:

I guess in our school, in our context, learning support to me is actually giving that extra support to those kids that need it, be it ESL, be it learning difficulties.

(Rosa, Learning Support)

Only two of the five teachers with management responsibilities had any tertiarylevel preparation for EAL, but this did not cause them concern because of the commonly held belief that learning in an additional language for EALs was the same as learning literacy skills, and they were confident literacy teachers. Furthermore, the relationship between learning subject content and learning an additional language seemed unclear, even to teachers with an interest in the process of language learning:

There's always the pressure to teach the content and the skills, you know, to get through. You can't spend all of your time just doing English language but you've got to because otherwise they can't do anything else.

(Rick, History)

This theme demonstrates how subject teachers felt confident about teaching EAL students. They reported having a good command of literacy strategies and applied approaches they had observed in primary schools. While these beliefs encouraged some teachers to consider metacognition, it was generally felt that EAL students were unlikely to take an academic path. Teachers reported that EAL students benefited from teaching discrete elements of language at the morpheme and word level rather than maintaining a focus on language function and meaning. However, some of these practices were inconsistent with their stated beliefs, and/or with established theories about language and language learning, as can be seen in Figure 2. 
Figure 2. Teachers' conceptions compared to practices from literature

Participants' beliefs about good teaching
(supported by language teaching
research)

Know the learner.

Share learning objectives from the curriculum, create success criteria, and ensure there are opportunities for feedback including self-assessment. Involve students in rich (cognitively challenging) tasks.

Maintain an explicit focus on language.

Model and deconstruct subject-related text types.

Use ICT extensively to allow opportunities to engage with text in different ways, and for motivation.

Encourage oral interaction that may include L1.
BUT Participants' misconceptions about teaching language learners (that lack empirical support)

Teaching adolescent EALs is the same as teaching primary students (young $\mathrm{L}_{1}$ learners), so simplify cognitive demands.

Teaching EALs is the same as teaching literacy to struggling Li learners, so reduce the curriculum and use the same literacy strategies as for $\mathrm{L}_{1}$ learners.

Simplify subject matter to orientate learning towards a practical/ community application.

Teach discrete elements of language (including spelling), then move up to the sentence and paragraph level.

Teach English language before attempting curriculum content.

Use ICT (e.g., an interactive whiteboard) as a language teaching strategy.

Prioritise whole class discussion.

\section{Discussion}

Despite the long-standing research showing that integration of language and content instruction across the curriculum is critical to meet the needs of culturally and linguistically diverse students in secondary schools, and the now official recognition of the need for an explicit focus on language in the content areas, the beliefs and practices of teachers in these two secondary schools do not seem to reflect these changed expectations.

\subsection{Knowledge about language}

The teachers in this study, most with decades of experience teaching in high-EALneed schools, identified a number of general but powerful teaching strategies that research identifies as effective in enhancing the learning of EALs, which may have been absorbed from prior professional learning. However, they appeared to have negligible specific knowledge about language gained from these years of professional learning. The participants seemed to share a common metalanguage, regardless of their subject area or familiarity with teaching EAL learners, includ- 
ing linguistic terminology such as: vocabulary, noun, verb, prefix, root word, sentence, paragraph, text, decoding, spelling, and reading age. This terminology did not cover field, mode, tenor, function, genres (other than recount), or reflect more than a superficial sense of text structure (Schleppegrell, 2013). This limited toolkit of language to describe how language functions in their content areas may have reflected a limited understanding of the workings of language, or a limited knowledge of how second languages are learnt; but appeared to circumscribe how they could unpack texts with their EAL students (Derewianka, 2012; Hammond \& Jones, 2012). Metalanguage requires technical vocabulary, the one aspect of language teachers are confident to teach, and which students expect to learn at secondary school (Gleeson, 2015). However, teachers in this study were wary of terms specific to language learning and defaulted to metalanguage familiar from their own education or acquired from valued (primary school or literacy) colleagues. The participant teachers cared very much about supporting their EAL students yet seemed unaware that they had gaps in their knowledge about language, or that these gaps had the potential to restrict their repertoire of support.

Perhaps an even greater concern was that the participants did not know that the Australian curriculum could offer them a great deal of linguistic support to understand how language shaped meaning in their particular subject areas. Data were gathered the same year as the Australian curriculum was published, yet none of the content area teachers was familiar with it. It commonly takes time for teachers to respond to educational initiatives but this lack of awareness was of concern for two reasons. Firstly, even though there is a specific curriculum strand within English for students with English as an additional language or dialect (EALD), this is not the only learning area where EALD students' learning is supported. The Australian curriculum is explicit about the text types and text structures covered in seven different key learning areas at every different level of the curriculum. In other words, the Australian curriculum spells out the language demands of each subject and so it has the potential to be a useful resource for teachers. This was overlooked. Secondly, the level of detail about the language specific to different key learning areas in the curriculum builds on more than 30 years of research into systemic functional linguistics, and almost as many years of teacher professional learning on the learning and teaching of EAL students. This raises the issue of what content-area teachers need to learn about language.

\subsection{What do content-area teachers need to learn about language?}

Content-area teachers appear to lack a solid understanding of the mechanics of learning and discussing language. They seem not to realise that English (second) language learning is a disciplinary area in its own right, with its own content, 
language and pedagogy (Bunch, 2013), and if they were to develop a "conscious awareness ... of the complex workings of the linguistic technology in construing [subject] knowledge, beliefs, and worldviews ... With such explicit knowledge and understanding, ... [they would] be in a better position to apprentice their students to 'scientific' ways of reading, writing, thinking, and reasoning" (Fang, 2005, p. 346).

Research from Australia (Derewianka, 2012) as well as internationally (Fang \& Schleppegrell, 2010) shows that mainstream teachers can use systemic functional linguistics (SFL) as a conceptual framework to enrich their understanding of how academic language works to shape disciplinary meaning. This contrasts with the insights knowledge about language (KAL) can offer teachers and learners. Schleppegrell's (2016) work illustrates how elementary school teachers and even very young EAL students can confidently use SFL structures to analyse and construct science texts. Other studies illustrate that SFL can also be used as a platform for building critical literacy and high-level thinking (O'Hallaron, Palinscar, \& Schleppegrell, 2015). This offers a stark contrast to the participant teachers' common-sense desire to build understanding through simplification. A SFL approach is additive in supporting teachers and learners to collectively make sense of how language is shaped for different academic purposes in a meaningful subject-matter context.

\subsection{When and how might teachers learn about language?}

The obvious options for learning about language are through pre-service and/or in-service programmes. Most initial teacher education programmes in Australia now include modules on teaching EAL students as part of their core course, and in UNSW this has been compulsory since 2009. However, only one participant reported taking a module related to EALs during her pre-service teacher education, with most teachers having graduated many years ago before such a requirement was mandated.

Similarly, with professional learning, modules about second language learning have been offered at state level for decades (Veel, 2006), and some of the participants in this study had completed relevant courses, such as TELL, but without follow up, only a few isolated practices had been integrated into the teachers' reportoires. Specialist TESOL qualifications are also available through many universities, though only one of the mainstream subject teachers in this study had received this training and it had been so long ago, he confessed to have forgotten the content as he now viewed his role as being a support to his subject teaching colleagues. 
Given research shows that content area teachers find it easier to engage with professional learning when it can be applied within their own teaching context over a sustained period of time (Echevarria, Vogt, \& Short, 2008), an alternative is "on the job" training, for example, partnership or team teaching, where EAL and subject teachers work together to share their complementary knowledge and expertise. Forms of partnership teaching have existed in Australia and elsewhere for more than 30 years with clear and explicit models of what works best (Davison, 2006). However, in the schools where the current study took place, partnership teaching was a routine and highly valued practice but did not appear to extend beyond the compliance and accommodation phases. The EAL teacher, while respected as a colleague, was not deferred to as an expert with specialist knowledge, nor did the content area teachers see them as someone from whom they could learn. While such partnerships are useful in sharing the teaching load when there are large numbers of EAL students in a class, they do not seem to provide reciprocal professional learning.

The development of online communities of practice such as Victoria's EAL network, hosted through the Tools for Enhancing Assessment Literacy for Teachers of EAL (TEAL), see http://teal.global2.vic.edu.au/, offers another way forward, with system level support to implement mandated changes and university partners to provide the research-informed input and expertise, but autonomy given to teachers to scaffold and support each other in their learning across schools and systems. Other partnership structures for professional learning occur between teachers and tertiary institutions. Walqui and van Lier's (2010) vision for teachers of EAL students includes some of the same practices espoused by the participant teachers as good teaching (Figure 2). However, they also add particular values and teaching strategies that the participants overlooked such as maintaining conceptual and intellectual rigour (not by simplifying but using scaffolding), increasing opportunities for student and teacher interaction, and sustaining a language focus. Both TEAL and the approach advocated by Walqui and Van Lier deploy an extended apprenticeship model involving participating teachers and EAL specialists working together over a sustained period of time. This supports other international evidence (Echevarria, Vogt, \& Short, 2008; Lee \& Buxton, 2013) that effective professional leaning in EAL needs to include sufficient subject content and active and collaborative learning in a coherent structure over an extended period of time. 


\section{Conclusions}

Despite much stronger official recognition of the needs of EAL students (leading to significant changes in pre-service and in-service education) and the development of many research-informed yet practical curriculum and assessment materials, this study suggests that very experienced content area teachers in linguistically and culturally diverse secondary schools still only have a relatively superficial understanding of the nature of language and EAL learning, and do not demonstrate much desire to learn more. Their perspectives and experiences of what makes good teaching have given them a repertoire of strategies that they feel are sufficient to meet EAL students' needs. However, the literature suggests that there are ways to encourage them to change these perceptions through more innovative models of online professional exchange and learning which require collaboration with EAL teachers and language experts to solve real world classroom problems such as improving assessment strategies and benchmarking student performance. In doing so, they may gain the confidence to integrate a more explicit focus on language into their content learning outcomes, then implement purposeful instructional techniques to promote English language learning as well as conceptual and skill development.

\section{References}

Australian Bureau of Statistics (ABS). (2018). 2016 census data summary, https://www.abs.gov .au/ausstats/abs@.nsf/Lookup/by\%2oSubject/2071.0 2016 Main\%2oFeatures Cultural \%20Diversity\%2oData\%2oSummary 30

Australian Curriculum and Reporting Authority (ACARA). (2012). The shape of the Australian curriculum (Version 4), https://docs.acara.edu.au/resources/The_Shape_of_the_Aus tralian_Curriculum_v4.pdf

Bunch, G.C. (2013). Pedagogical language knowledge: Preparing mainstream teachers for English learners in the new standards era. Review of Research in Education, 37, 298-341. https://doi.org/10.3102/0091732X12461772

Christie, F., \& Derewianka, B. (2010). School discourse: Learning to write across the years of schooling. Hong Kong: A\&C Black.

Cummins, J., \& Early, M. (Eds.). (2011). Identity texts: The collaborative creation of power in multilingual schools. Stoke-on-Trent: Trentham Books.

Davison, C. (1988). The role of language in the post-primary classroom. In Davison, C. (Ed.), "But this isn't science, Miss": The Language across the Curriculum Project in Victoria (pp. 16-26). Victoria, Australia: Ministry of Education.

Davison, C. (1993). Integrating ESL into the mainstream: Australian perspectives. Multicultural Teaching, 11(3), 35-40. 
Davison, C. (2006). Collaboration between ESL and content teachers: How do we know when we are doing it right? International Journal of Bilingual Education \& Bilingualism, 9(4), 454-475. https://doi.org/10.2167/beb339.0

Davison, C., \& Williams, A. (2001). Integrating language and content: Unresolved issues. In B. Mohan, C. Leung, \& C. Davison (Eds.), English as a second language in the mainstream: Teaching, learning and identity (pp. 51-70). Harlow: Longman Pearson.

De Oliveira, L.C., \& Lan, S.-W. (2014). Writing science in an upper elementary classroom: A genre-based approach to teaching English language learners. Journal of Second Language Writing, 25, 23-39. https://doi.org/10.1016/j.jslw.2014.05.001

Department of Education NSW. (n.d.). Teaching English language learners (TELL). Retrieved from https://beta.dec.nsw.gov.au/__data/assets/pdf_file/ooo4/271498/Flyer-EOI-for-host -schools-TELL-PL-2017.pdf

Derewianka, B. (2012). Knowledge about language in the Australian curriculum: English. Australian Journal of Language and Literacy, 35(1), 127-146.

Echevarria, J., Frey, N., \& Fisher, D. (2015). What it takes for English learners to succeed. Educational Leadership, 72(6), 22-26.

Echevarria, J., Vogt, M., \& Short, D. (2008). Making content comprehensible for English learners: The SIOP model. Boston: Pearson Education Ltd.

Fang, Z. (2005). Scientific literacy: A systemic functional linguistics perspective. Science education, 89(2), 335-347. https://doi.org/10.1002/sce.20050

Fang, Z., \& Schleppegrell, M.J. (2010). Disciplinary literacies across content areas: Supporting secondary reading through functional language analysis. Journal of Adolescent \& Adult Literacy, 53(7), 587-597. https://doi.org/10.1598/JAAL.53.7.6

Gibbons, P. (2008). "It was good and I learnt a lot": Intellectual practices and ESL learners in the middle years. Australian Journal of Language and Literacy, 31(2), 155-173.

Gibbons, P. (2009). English learners, academic literacy and thinking: Learning in the Challenge Zone. New York: Heinemann.

Gibbons, P. (2014). Scaffolding language, scaffolding learning. Teaching second language learners in the mainstream classroom (2nd ed.). Portsmouth: Heinemann.

Gleeson, M. (2015). 'It's the nature of the subject': Secondary teachers' disciplinary beliefs and decisions about teaching academic language in their content classes. Australian Journal of Language and Literacy, 38(2), 104-114.

Gleeson, M., \& Davison, C. (2016). A conflict between experience and professional learning: Subject teachers' beliefs about teaching English language learners. RELC Journal, 47(1), 43-57. https://doi.org/10.1177/0033688216631221

Halliday, M.A. K. (1993). Towards a language-based theory of learning. Linguistics and Education, 5(2), 93-116. https://doi.org/10.1016/0898-5898(93)90026-7

Hammond, J. (2014). An Australian perspective on standards-based education, teacher knowledge, and students of English as an additional language. TESOL Quarterly, 48(3), 507-532. https://doi.org/10.1002/tesq.173

Hammond, J., \& Jones, P. (2012). Knowledge about language and the Australian curriculum: Implications for teachers and students. Australian Journal of Language and Literacy, 35(2), 122-125.

Hurst, D., \& Davison, C. (2005). Collaborating on the curriculum: Focus on secondary ESOL. In J. Crandall \& D. Kaufman (Eds.), Content-based instruction in primary and secondary school settings (pp. 41-66). Alexandria, VA: TESOL. 
Lee, O., \& Buxton, C.A. (2013). Teacher professional development to improve science and literacy achievement of English language learners. Theory into Practice, 52(2), 110-117. https://doi.org/10.1080/00405841.2013.770328

Lo Bianco, J. (1990). Making language policy: Australia’s experience. In R. B. J. Baldauf \&

A. Luke (Eds.), Language planning and education in Australasia and the South Pacific (pp. 1-22). Philadelphia, Clevedon: Multilingual Matters.

Love, K. (2010). Literacy pedagogical content knowledge in the secondary curriculum. Pedagogies, 5(4), 338-355. https://doi.org/10.1080/1554480X.2010.521630

Love, K., \& Humphrey, S. (2012). A multi-level language toolkit for the Australian Curriculum: English. Australian Journal of Language and Literacy, 35(2), 173-191.

Martin, J.R. (2013). Embedded literacy: Knowledge as meaning. Linguistics and Education, 24(1), 23-37. https://doi.org/10.1016/j.linged.2012.11.006

Martin, J.R., \& Rose, D. (2008). Genre relations: Mapping culture. Australian Journal of Linguistics, $30(2), 376-380$.

Masny, D. (1997). Linguistic awareness and writing: Exploring the relationship with language awareness. Language Awareness, 6(2-3), 105-118. https://doi.org/10.1080/09658416.1997.9959921

Morgan, C., Craig, T., Schuette, M., \& Wagner, D. (2014). Language and communication in mathematics education: an overview of research in the field. ZDM, 46(6), 843-853. https://doi.org/10.1007/s11858-014-0624-9

New South Wales (NSW) Education Standards Authority (NESA). (2017). NSW supplementary documentation: Elaborations in priority areas. Retrieved from http:// educationstandards.nsw.edu.au/wps/wcm/connect/603968do-871e-4foe-82of$98 \mathrm{~d} 6 \mathrm{dfc} 736 \mathrm{ff} /$ elaboration-in-priority-areas.pdf?MOD=AJPERES\&CVID=

O'Hallaron, C.L., Palinscar, A.S., \& Schleppegrell, M.J. (2015). Reading science: Using systemic functional linguistics to support critical language awareness. Linguistics and Education, 32, Part A, 55-67. https://doi.org/10.1016/j.linged.2015.02.002

Ollerhead, S. (2017). Pedagogical language knowledge: Preparing Australian pre-service teachers to support English language learners. Asia-Pacific Journal of Teacher Education 46(3), 256-266. https://doi.org/10.1080/1359866X.2016.1246651

Phillips, L. M., \& Norris, S.P. (2009). Bridging the gap between the language of science and the language of school science through the use of adapted primary literature. Research in Science Education, 39(3), 313-319. https://doi.org/10.1007/s11165-008-9111-z

Polat, N., \& Mahalingappa, L. (2013). Pre- and in-service teachers' beliefs about ELLs in content area classes: A case for inclusion, responsibility, and instructional support. Teaching Education, 24(1), 58-83. https://doi.org/10.1080/10476210.2012.713930

Premier, J.A., \& Miller, J. (2010). Preparing pre-service teachers for multicultural classrooms. Australian Journal of Teacher Education, 35(2), 35-48. https://doi.org/10.14221/ajte.2010v35n2.3

Reeves, J.R. (2006). Secondary teacher attitudes toward including English-language learners in mainstream classrooms. Journal of Educational Research, 99(3), 131-142. https://doi.org/10.3200/JOER.99.3.131-143

Rose, D., \& Martin, J.R. (2012). Learning to write, reading to learn: Genre, knowledge and pedagogy in the Sydney School. Sheffield: Equinox.

Schleppegrell, M. J. (2013). The role of metalanguage supporting academic language development. Language Learning, 63, 153-170. https://doi.org/10.1111/j.1467-9922.2012.00742.x 
Schleppegrell, M.J. (2016). Content-based language teaching with functional grammar in the elementary school. Language Teaching, 49(1), 116-128. https://doi.org/10.1017/So261444814000093

Seah, L.H., Clarke, D. J., \& Hart, C. (2011). Understanding students' language use about expansion through analyzing their lexicogrammatical resources. Science Education, 95(5), 852-876. https://doi.org/10.1002/sce.20448

Turkan, S., de Oliveira, L., Lee, O., \& Phelps, G. (2014). Proposing a knowledge base for teaching academic content to English language learners: Disciplinary linguistic knowledge. Teachers College Record, 116(1), 1-30.

Unsworth, L. (1999). Developing critical understanding of the specialised language of school science and history texts: A functional grammatical perspective. Journal of Adolescent \& Adult Literacy, 42(7), 508.

Veel, R. (1997). Learning how to mean- scientifically speaking: Apprenticeship into scientific discourse in the secondary school. In F. Christie \& J. R. Martin (Eds.), Genre and institutions: Social processes in the workplace and school (pp. 161-195). London and Washington: Cassell.

Veel, R. (2006). The Write it Right project - Linguistic modelling of secondary school and the workplace. In R. Whittaker, M. O’Donnell, \& A. McCabe (Eds.), Language and literacy: Functional approaches (pp. 66-92). London and New York: Continuum.

Walqui, A., \& van Lier, L. (2010). Scaffolding the academic success of adolescent English language learners. San Francisco: WestEd.

Wellington, J., \& Osborne, J. (2001). Language and literacy in science education. UK: McGrawHill Education.

\section{Address for correspondence}

Margaret Gleeson

School of Education

Victoria University Wellington

New Zealand

margaret.gleeson@vuw.ac.nz

\section{Co-author information}

\section{Chris Davison}

School of Education

University of New South Wales

c.davison@unsw.edu.au 
[22] Margaret Gleeson and Chris Davison

Author Query

- Please provide a complete reference for the citation '(Halliday's (1978))' in this article. 